\title{
化学反応を駆動源とする自励振動アクチュエータの開発と マイクロ流体素子への応用
}

\author{
産業技術総合研究所 ナノシステム研究部門
}

原 雄介

\begin{abstract}
Development of autonomous actuators and application to micro fluid devices
In this review, I introduce the function and the application field of the self-oscillating polymer system that can drive without the external stimuli under the constant temperature conditions. The driving force of the self-oscillating polymer system is produced by the dissipating chemical energy of the Belouzov-Zhabotinsky (BZ) reaction. The BZ reaction is well known as an oscillating reaction accompanying spontaneous redox oscillations to generate a wide variety of nonlinear phenomena, e.g., a target or spiral pattern in an unstirred solution, and periodicity, multi-periodicity, or chaos in a stirred solution. The overall process of the BZ reaction is the oxidation of an organic substrate by an oxidizing agent in the presence of the catalyst under strong acidic condition. In the $\mathrm{BZ}$ reaction, the metal catalyst undergoes spontaneous redox self-oscillation, and it changes the solubility from hydrophilic to hydrophobic at the same time. The polymer system realized the self-oscillation by synchronize with the periodical solubility change of the Ru catalyst moiety. In recent years, the self-oscillating polymer system improved the molecular design in order to apply to micro fluid devices. The micro fluid devices with the self-oscillating polymer actuator do not need a power supply and external control devices.

自励振動アクチュエータは、心筋細胞のように外部刺激によらず自励駆動する時空間機能を有した ソフトマテリアルである。このような機能は、Belousov-Zhabotinsky（BZ）反応によって高分子 鎖の溶存状態を周期的に変化させることによって発現している。化学反応を直接的に力学的なエネル ギーに変換して駆動する自励振動アクチュエータは、外部電源および外部制御装置フリーで駆動する ことを特徵とする。本稿では、分子デザインを改良することで高機能化が進む自励振動アクチュエー タを、ラボオンチップ等の微細空間で活躍するマイクロ流体素子 (マイクロポンプ等) の動力源とし て機能させることを目指した研究の現状について紹介する。
\end{abstract}

Yusuke Hara

Keywords: BZ reaction, gel, actuator, micro fluid device, micro pump

\section{高分子アクチュエータについて}

外部刺激に応答して高分子鎖のコンフォメーショ ンを変化させる刺激応答性高分子(リニアポリマー) や膨潤収縮率が変化する刺激応答性ゲルは、これま で基礎から応用まで幅広く研究が行われてきた。特 に温度応答性を有するポリーNーイソプロピルアクリ ルアミドゲル (PNIPAAm) は，一次相転移である 体積相転移現象が故田中豊一（MIT）らによって見 い出されて以来, 細胞の接着性制御や薬物放出デ

* Nanosystem Research Institute(NRI), National Institute of Advanced Science and Technology(AIST)
バイスなど様々な応用展開がなされてきた ${ }^{1 \sim 10)} 。 一$ 方、電気的な刺激に応答する刺激応答性高分子を 用いて、高分子アクチュエータへの応用を図った 研究も盛んに行われている ${ }^{11 \sim 13)}$ 。高分子アクチュ エータは、軽量 · 柔軟 · 成形加工性の高さを特徵と し、有機材料で構成されているため金属疲労が発生 せず、無音で駆動することを特徵としている。高分 子素材の柔軟性から、電磁モーターやギヤから構成 されるアクチュエータと比較して、非常に柔らかい 動きを簡単につくりだすことができる。また、電磁 モーターのように発熱しないことも、高分子アク チュエータの特徵として挙げることができる。これ 
までの機械駆動の分野にない特徴を有する高分子ア クチュエータは、半導体微細加工技術の著しい発展 から、MEMS やラボオンチップの微細空間で機能 するマイクロ流体素子として活用することが切望さ れている。なぜならば、電磁モーターやギヤから構 成されるアクチュエータを微細化することは非常に 難しく、作製のためには高コスト・高エネルギーを かける必要性があるため経済的にも合理的な選択で はないからである。そのため、筋肉同様にスケール 普遍性を持つ高分子アクチュエータの実用化が望ま れていた。【筋肉は、スケールによらず同程度の効 率で力を出すことができる。小さな虫も、巨大な象 も基本的には同じ構造の筋肉組織から構成されるの は、筋肉のスケール普遍性による。高分子アクチュ エータのスケール普遍性から、マクロに機能を果た すアクチュエータの開発に成功すれば、微細化して も同様の働きが得られることが保障される。高分子 アクチュエータは、合成時に使用する鋳型さえ微細 化すればスケールダウンは安易である。また特徵と する素子の柔らかさから、切断による加工でも微細 なものを作製することができる。さらに、高分子ア クチュエータは、柔軟な駆動が特徵であることから 電磁モーターやギヤからなるアクチュエータに比べ て、微細空間においても多自由度のアクチュエータ をより簡便に作製可能なメリットを有している。作 製段階においても、UV や低温の温度環境で合成可 能な高分子も多いため、作製時に必要なエネルギー コストが小さいことも特徵として挙げられる。

\section{ラボオンチップに求められるアクチュエータについて}

高分子アクチュエータの電磁モー夕等にはない特 徵を活かして、ラボオンチップのような微細な空 間で活躍するマイクロアクチュエータやマイクロ ロボットへの応用研究が活発に行われている ${ }^{14 \sim 16) 。 ~}$ ラボオンチップは、医療診断や健康管理、環境分析 を担うマイクロデバイスや省資源の物質生産や創薬 が可能なオンデマンド化学合成チップなどへの応用 が可能である。近年、特に病気の予防に重点を置い たヘルスケア分野への応用が特に注目され、活発に 研究が進められている。ラボオンチップのようなマ
イクロ流体システムの実現には、マイクロ流体素 子（マイクロポンプ、マイクロバルブ、マイクロア クチュエータなど)が欠かせない技術となっている。 スケール普遍性を持つ高分子アクチュエータは、素 子の微細化が安易であるため、マイクロ流体素子へ の応用には適している。Jager らは MEMS やラボ オンチップ等の微細空間で活躍する導電性高分子か らなるマイクロロボットアームの作製を行い、注目 を浴びた $^{17 \sim 18)}$ 。高分子素材からなるマイクロロボッ トアームの特徽は、そのしなやかさと柔軟さにある。 電磁モーターやギヤのような硬い材料から構成され るアクチュエータでは、微細な空間で柔軟な動きを 出すことは非常に難しい。また導電性高分子・ポリ ピロールからなる Jager らのマイクロロボットアー ムは水中で動作可能なことから、例えば単一の細胞 操作や特性解析に用いることも可能である点が優れ ている。しかしながら、導電性高分子からなるマイ クロアクチュエータにも欠点がある。導電性高分子 等の電気刺激によって駆動する高分子アクチユエー 夕は、素子を動作させるための配線設計が煩雑であ る。また素子に対して非常に大きな外部制御装置や バッテリー等の外部電源が必須であることから、使 用場面が限定されていた。先進国の高齢化が進む社 会においては、ラボオンチップは家庭に扮ける健康 管理や診断への応用が特に期待されている。自宅に いながらラボオンチップで健康診断等を進めるため には、外部制御装置や外部電源を含めたシステム全 体を含めたマイクロ流体素子(マイクロポンプ等)の 微細化とコストダウンが必要不可欠となる。もし外 部電源や制御装置不要で駆動する高分子アクチュ エータが得られれば、自宅や屋外で使用可能なディ スポーサルタイプの廉価なラボオンチップの実現が 可能となる。このようなチップを作製するためには、 配線設計の必要性がなく、外部装置が不要な新規ア クチュエータの開発が必要不可欠な状況にあった。 近年、森島 (阪大) らのグループは、自励駆動するア クチュエータの開発を目指して、心筋細胞を用いた マイクロポンプやマイクロピラーの作製を行ってい る $^{19 \sim 21)}$ 。より多方面にマイクロポンプ等のマイクロ 流体素子を活用するためには、必要に応じてその形 状や発生力、駆動周波数を任意に制御することがで 
き、腐ることがなく耐久性の高い完全人工合成型の 自励振動アクチュエータの開発が切望される状況に あった。このような要請から筆者らは、化学反応を 直接的に力学的なエネルギーに変換して駆動する自 励振動アクチュエータを動力源とするマイクロ流体 素子の開発を行っている。自励振動アクチュエータ は、化学反応で自励的に駆動するため外部電源抏よ び外部制御装置を必要としない。また生体関連物質 を使用しない合成高分子であるため、高い耐久性を 有していることも特徵として挙げられる。

\section{自励振動アクチュエータ}

生命体は生体内部で起こる多段かつ並行的な多数 の生化学反応を巧みに利用することで、何ら外部の 刺激に頼ることなく、流入するエネルギーと生体内 部で散冕するエネルギーが均衡して、一定の散冕構 造を保つ、非平衡開放系の分子システムである。そ の生体内部には、神経細胞の膜電位、心臓の拍動、 サーカディアンリズムなど、細胞レベルから一個体 に至るまでのあらゆる階層おけるリズムを包括して いる。それらのリズムは、外部刺激によってそのリ
ズムが乱されたとしても、再びそれぞれの持ってい た振動リズムに復帰する力強さを内包している。こ のような動的で周期秩序を有する分子システムをテ イラーメイドで構築することができれば、外部の環 境を認識しながらも自励的に駆動する、生命体のよ うな分子システムが構築できる。生命体のような分 子システムは、これまでの刺激応答性材料と異な り、その形態変化(出力)を起こすために、スイッチ として常に温度や電場などの外部刺激 (入力) を必要 としない。本研究では必要に応じてその形状や発生 力、駆動周波数を任意に制御することができ、耐久 性が高い自励駆動する高分子アクチュエータの構 築に向けて自らリズムを発し、周期的なパルスや 空間パターンを生み出す非線形反応として知られ ている Belousov-Zhabotinsky（BZ）反応に注目した (図 1 ${ }^{22 \sim 28)}$ 。 BZ 反応は、代謝反応との類似性が多 く、情報伝達や自己組織化などの種々の生命現象を 理解するための化学モデルとしてその重要性が認識 されている。

これまで、BZ 反応を駆動源としてポリマー鎖を 駆動させる研究として、石渡 (信州大)らがリニアポ リマー ${ }^{29}$ )で、また吉田(東大)らが化学架橋構造を有

リズムとパターンを形成するBelousov-Zhabotinsky (BZ) 反応

Reactants

- Organic acid: malonic acid (MA), citric acid, etc. - Oxidizing agent: $\mathrm{NaBrO}_{3}, \mathrm{KBrO}_{3}$, etc.

- Acid: $\mathrm{H}_{2} \mathrm{SO}_{4}, \mathrm{HNO}_{3}$, etc.

- Catalyst: $\mathrm{Ce}^{3+/ 4+}, \mathrm{Fe}(\text { phen })_{3}{ }^{2+/ 3+}, \mathrm{Ru}(\mathrm{bpy})_{3}{ }^{2+/ 3+}$, etc.

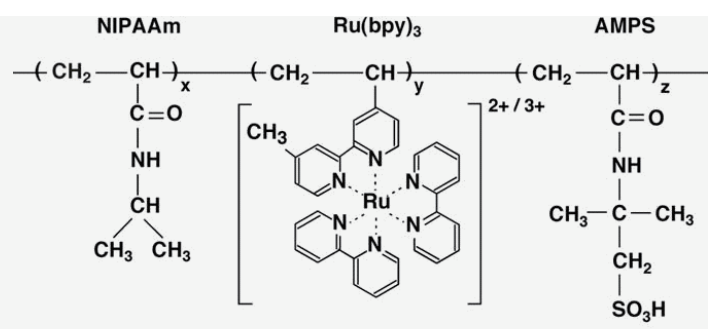

全体の反応:

$2 \mathrm{BrO}_{3}+3 \mathrm{CH}_{2}(\mathrm{COOH})_{2}+2 \mathrm{H}^{+} \rightarrow 2 \mathrm{BrCH}(\mathrm{COOH})_{2}+4 \mathrm{H}_{2} \mathrm{O}+3 \mathrm{CO}_{2}$ （酸化剂による有機物の酸化反応）

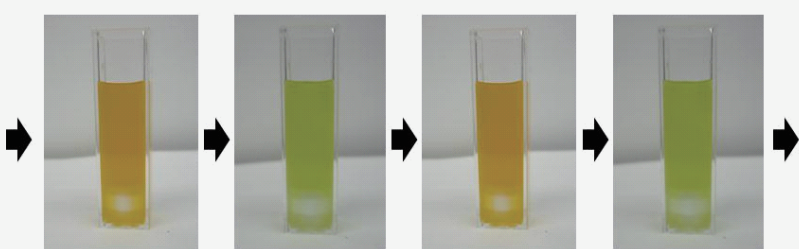

Reduced State Oxidized State Reduced State Oxidized State

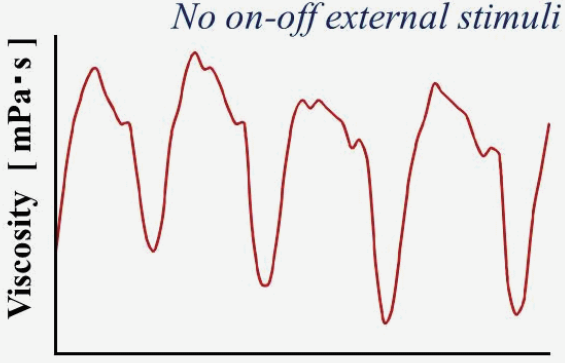

Time [s ]

図 1 リズムとパターンを形成する Belousov-Zhabotinsky（BZ）反応と自励振動高分子 
するゲル ${ }^{30)}$ の合成に成功している（図 2)。これら自 励振動高分子は、BZ 反応触媒である $\mathrm{Ru}(\mathrm{bpy})_{3}$ を 高分子鎖に内包することによって達成している。ポ リマー鎖内に導入された Ru（bpy) 3 部位は、酸化状 態 $(\mathrm{Ru}(\mathrm{II}))$ と還元状態 $(\mathrm{Ru}(\mathrm{II}))$ で溶解性が変化す る。そのため、BZ 反応場における $\mathrm{Ru}(\mathrm{bpy})_{3}$ 部位 の周期的な酸化還元状態の変化によって、ポリマー 鎖の溶解性が周期的に変化するため、リニアポリ マーでは凝集・解離の周期的変化を透過率振動とし て、またゲルでは膨潤収縮挙動として観測すること ができる。架橋構造を有する自励振動ゲルは、化学 反応を直接的に力学的なエネルギーに変換して体積 振動を起こすことが可能であるためアクチュエータ として使用可能な点で特に優れている。自励振動ゲ ルからなる自励振動アクチュエータの特徵として、 化学エネルギーを駆動源とするため外部電源が必要 なく、周期的に駆動させるための外部制御システム も必要としない点が挙げられる。化学反応で駆動す るため、エネルギー効率も非常に高いことが予想さ れており、現在実測を行っている。自励振動アクチュ エータは、他の小型アクチュエータに対して電源や 外部制御装置を含めた単位重量当たりの発生力が大 きいことが優位な特徴として挙げられる。また高分 子アクチュエータ特有のスケール普遍性を有するた め、性能を落とすことなく微細化することが可能で ある。またエネルギー源を含めても $1 \sim 2 \mathrm{~mm}^{3}$ 程度 の自励振動アクチュエータで 5 円から 10 円程度と 作製コストが従来品に比べて非常に安いことも特徵
としている。このような廉価なアクチユエータが実 用化されれば、マイクロ流体素子を含めたラボオン チップのディスポーサル化が可能となる。またアク チユエータを駆動させるための外部電源・外部装置 フリーのメリットを活かせば、屋外や家庭でのその 場診断を可能とするラボオンチップの実現が可能と なる。しかしながら、これまでの自励振動アクチュ エータの分子デザインでは、その駆動環境が BZ 反 応場(強酸環境)に固定されており、安全性の観点か ら応用の範囲が限定されていた。また駆動変位が小 さく、駆動速度も遅いため、マイクロ流体素子を駆 動させるアクチュエータへと応用するためには大幅 な改良が必要であった。

\section{自励振動アクチュエータの高機能化}

自励振動アクチュエータの駆動環境を生体環境下 のような非常にマイルドな環境まで拡張させること ができれば、ポンプ等をより安全性の高い環境下で 駆動させることが可能になり、その適用範囲を拡張 させることが可能となる。駆動環境の拡張を目指し て、まず BZ 反応に必要不可欠な酸性環境を自らつ くりだす部位(図 3)と、臭素酸を自ら供給する部位 を内包した新規自励振動型高分子をそれぞれ合成 し、酸無添加 ${ }^{31} 32$ 、または酸化剂無添加条件下 ${ }^{33)}$ 自励振動を起こすことに成功している。一連の研究 の中で、酸供給部位を持つ自励振動型高分子を高濃 度に溶解させれば、酸無添加条件でポリマー鎖の溶

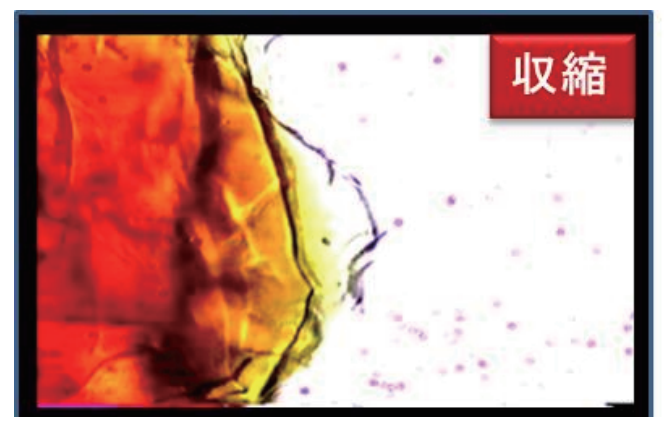

自励

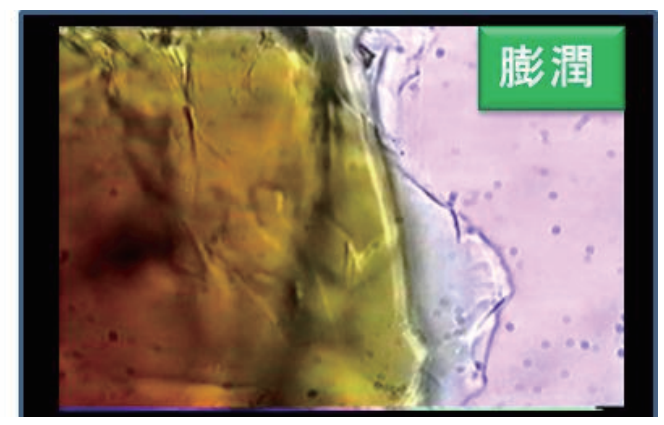

図 2 BZ 反応を駆動源として膨潤収縮する自励振動高分子 
存状態自励的変化に起因する自励粘性振動を捉える ことにも成功している ${ }^{34)}$ 。最終的には酸供給部位と 酸化剂供給部位を合わせ持つ新規自励振動型高分子 を合成することにより、マロン酸を加えるだけで自 励振動を起こすことに成功している ${ }^{35)}$ 。現在、この ような分子設計指針を基に、自励振動アクチュエー 夕の開発を行っており、より安全性の高い環境でマ
イクロ流体素子を駆動させるべくアクチュエータの 改良検討を行っている。

また、これまで開発されてきた自励振動ゲルの駆 動変位は非常に小さく、ロボットやアクチュエータ に用いるためには困難な状況にあった。自励振動ゲ ルの化学組成や重合方法を工夫することで、従来型 の自励振動型ゲルに比べて駆動変位が 20 倍以上大

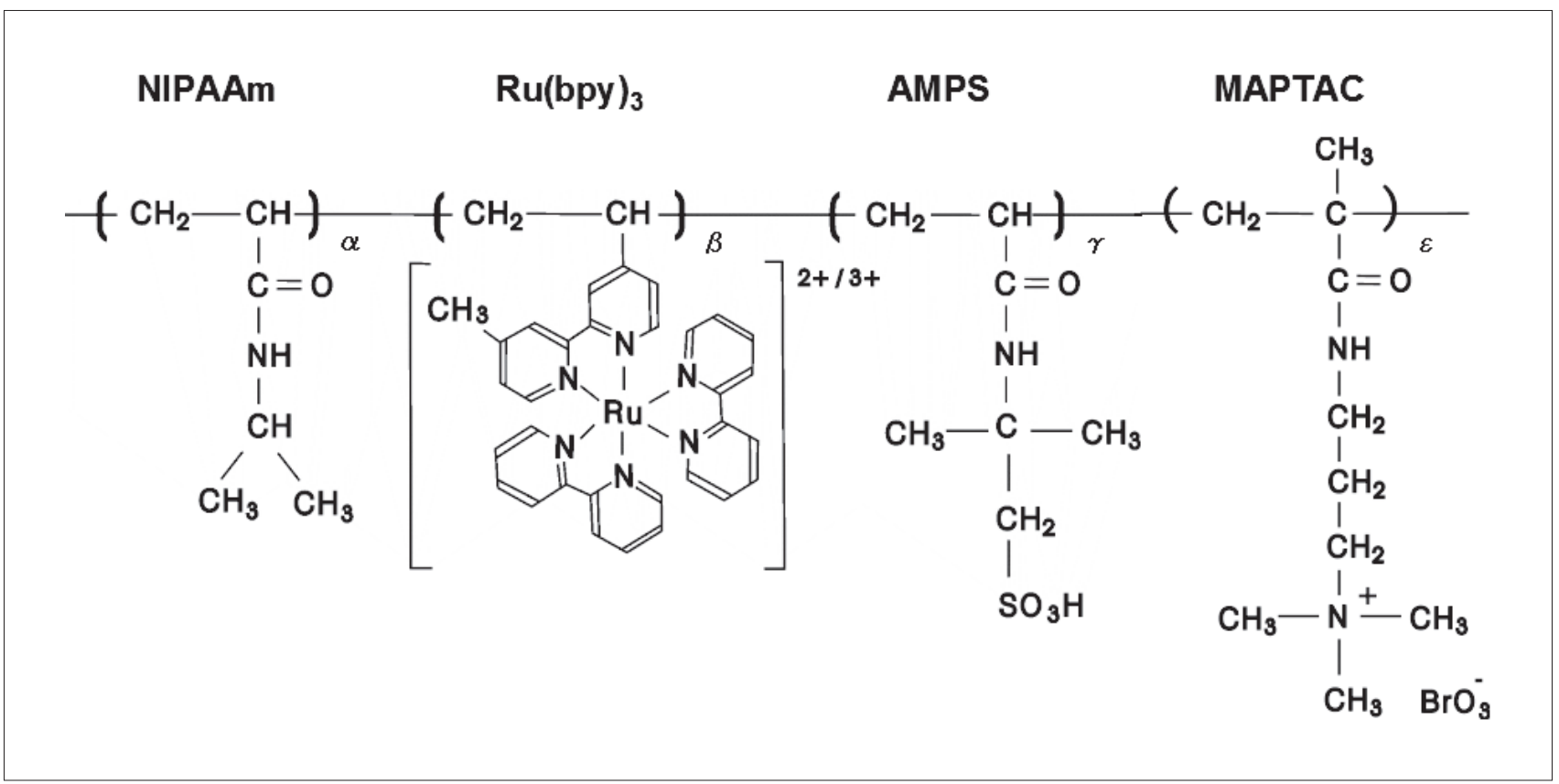

図３、ロン酸のみのマイルドな環境で駆動する新規自励振動高分子
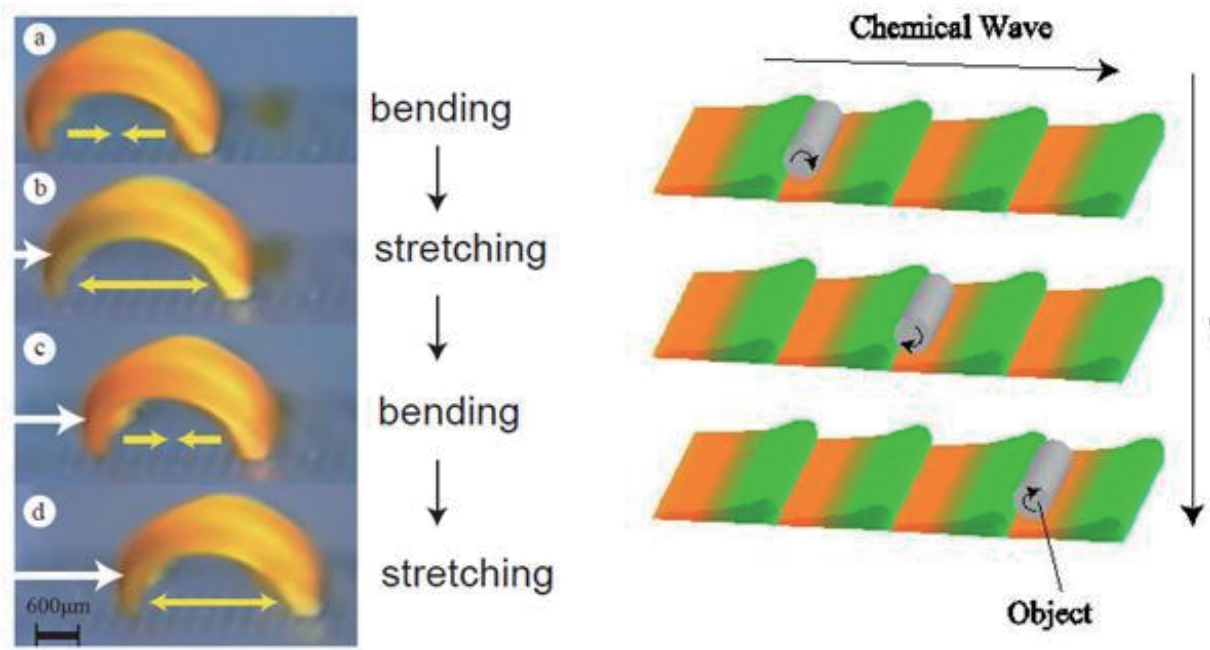

(1)

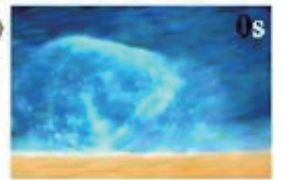

(2)

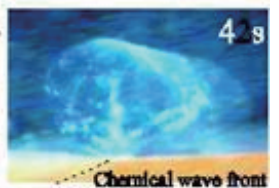

Time

(3)

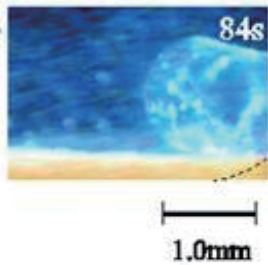

図 4 自励歩行ゲルおよびゲルコンベヤーシステム

(Reprinted ref. 40, Copyright Wiley-VCH Verlag GmbH \& Co. KGaA. Reproduced with permission.) 
きな自励振動ゲルの開発に成功している。改善さ れたゲルの大きな駆動変位を利用することで、ア クチュエータや自励歩行ゲル、表面の蠕動運動を 利用した物質輸送システムの開発に成功している

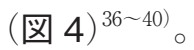

また、ポンプ等として駆動させるためには、駆 動周波数の改善が求められていた。現状の自励振 動ゲルの駆動周波数は遅いため、その改善検討が 必要不可欠だった。このような欠点を改善するた め、筆者らは自励振動ゲルの主鎖を温度応答性のな いものに変換することで、最大 $0.5 \mathrm{~Hz}$ の周波数で 駆動可能な新規自励振動ゲルの開発に成功している
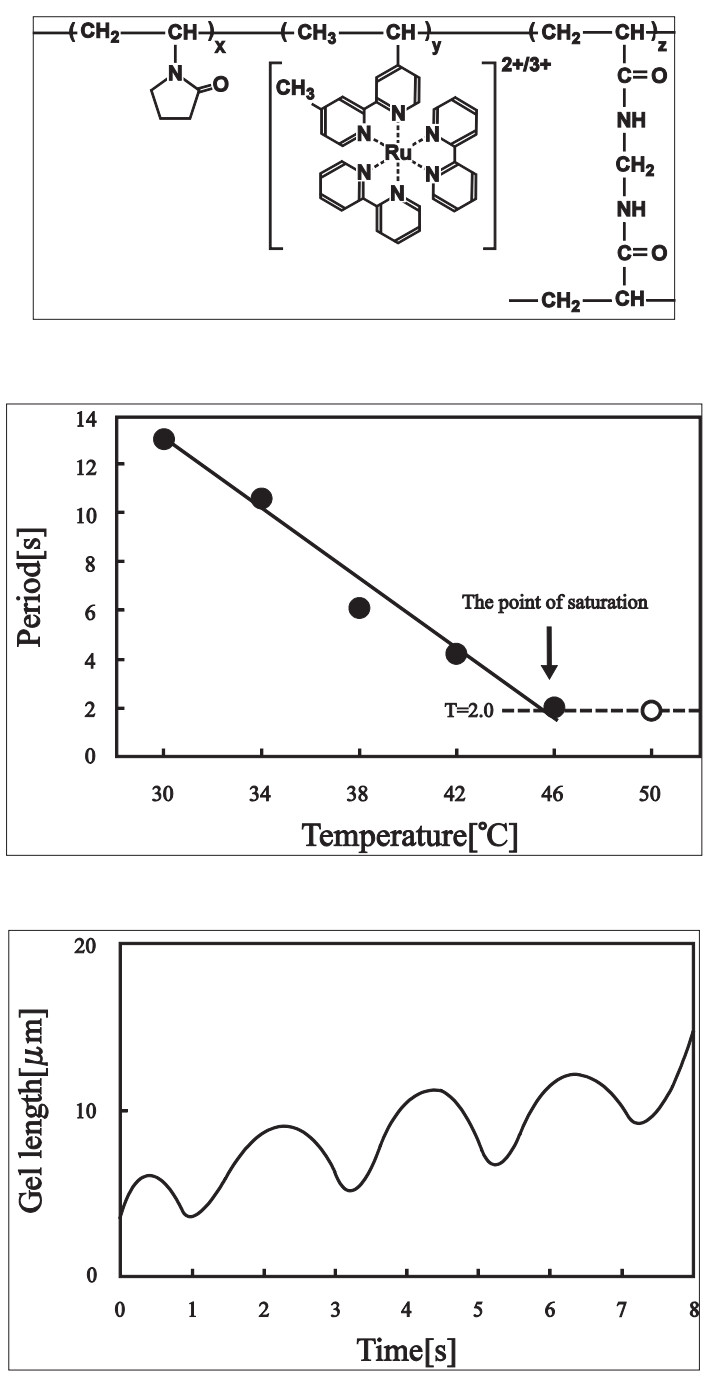

図 5 高速駆動する新規自振動アクチュエータ

(Reprinted ref. 41, Copyright American Chemical Society. Reproduced with permission.)
(図 5) ${ }^{41)}$ 。このような知見を活かすことで、高速駆 動が可能なポンプ等のマイクロ流体素子の開発に向 けて現在検討を進めている(図 6)。

さらにマイクロ流素子の内部で動力源として自励 振動ゲルを駆動させるためには、その振動挙動を 自在に On-Off 制御することも必要不可欠な技術と なってくる。自励振動型高分子にアニオンとカチ オン部位を同時に内包させることで、振動中の凝 集状態をコントロール可能なことを見い出し、段 階的な外部温度のコントロールによって振動挙動 を On-Off スイッチングさせることに成功している $\left(\right.$ 図 7 ${ }^{42}$ 。

\section{収縮時}
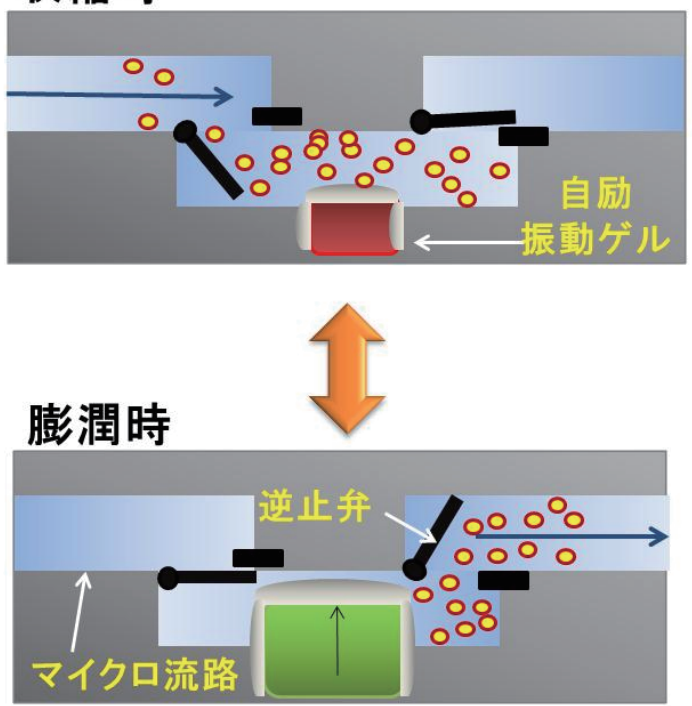

図 6 自励振動アクチュエータを動力源とするマイクロポンプ

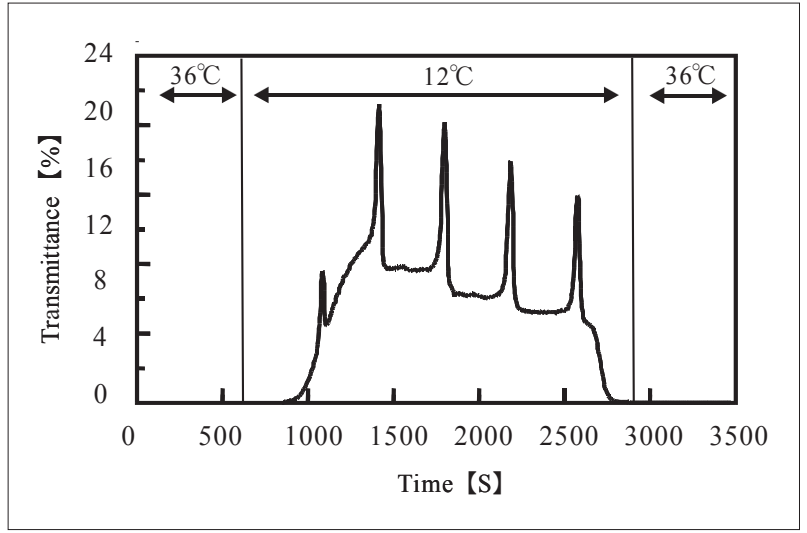

図 7 外部温度制御による振動挙動の On-Off スイッチング (Reprinted ref. 42, Copyright American Chemical Society. Reproduced with permission.) 


\section{おわりに}

これまでの研究で、外部電源・外部装置フリーの 自励振動アクチュエータをマイクロ流体素子へ応用 するためには必要不可欠な、マイルド環境で駆動さ せるための分子設計、高い膨潤度を実現させるため の分子設計、高速駆動させるための分子設計、また On-Off スイッチングさせるための分子設計につい て明らかになっている。現在、筆者らはこれらの知 見を合わせて、ラボオンチップ内部で駆動するため に最適な自励振動ゲルを開発するとともに、微細空 間で活躍するマイクロ流体素子の動力源として活用 することを検討している。またマイクロ流体素子へ 応用するためには必要不可欠なゲルアクチュエータ の発生力を水中で簡便・正確に測定可能な装置の開
発に成功し、自励振動ゲルの発生力測定を行ってい る。発生力および駆動変位のデー夕を基に、現在マ イクロポンプ等のマイクロ流体素子の開発を急ピッ チに進めており、これまで市場になかった新たな商 品を生み出すべく検討中である。

\section{謝辞}

最後に本研究を進めるにあたり、ご指導をいただきまし た吉田亮教授 (東京大学)、橋本周司教授 (早稲田大学) に感 謝を申し上げます。ここで紹介した研究の一部は、平成 23 年度先導的産業技術創出事業 (若手研究グラント) ・「化学反 応を駆動源とする超省エネ型・新規自励振動ゲルアクチュ エータを用いた外部装置フリーのマイクロ流体素子の開発」 の支援を受けて行われた。

\section{文献}

1) Steinberg, I, Z.; Oplatka, A.; Kachalsky, A. (1966). Mechanochemical Engines, Nature, 210, pp. 568-571.

2) Harada, A. ; Kataoka, K. (1999). Chain length recognition: core-shell supramolecular assembly from oppositely charged block copolymers. Science, 283, pp. 65-67.

3) Kim, J.; Nayak, S.; Lyon, L. A. (2005). Bioresponsive hydrogel microlenses, Journal of the American Chemical Society, 127, pp. 9588-9592.

4) Hoffman, A. S. (2002) Hydrogels for biomedical applications, Advanced Drug Delivery Reviews, 43, pp. 3-12.

5) Tanaka, T. (1981). Gels, Scientific American.,244, pp.110-116.

6) Hirokawa, Y.; Tanaka, T. (1984). Volume phase transition in a non ionic gel, Journal of chemical Physics, 81, pp.6379. 6380 .

7) Ilmain, F.; Tanaka, T., Kokufuta, E. (1991). Volume transition in a gel by hydrogen bonding, Nature, 349, pp.400-401.

8) Tanaka, T. (1978). Collapse of gels and critical endpoint, Physical Review Letters, 40, pp.820-823.

9) Suzuki, A.; Tanaka, T. (1990). Phase transition in a polymer gels induced by visible-light, Nature, 346, pp. 345-347.

10) Hu, Z.; Zhang, X. \& Li, Y. (1995). Synthesis and Application of Modulated polymer gels. Science, Vol.269, No.5223, (April 1995), pp. 525-527.

11) Fukushima, T.; Asaka, K.; Kosaka, A.; Aida, T. (2005). Fully plastic actuator through layer-by-layer casting with ionicliquid-based bucky gel. Angewandte Chemie International Edition, 44, pp.2410-2413.

12) Oguro, K.; Kawami, Y.; Takenaka, H. (1992). An actuator element of polyelectrotyte gel membrane-electrode composite, Bulletin of the Government Industrial Research Institute, Osaka, 43, pp. 21-24.

13) Otake, M.; Kagami, Y.; Inaba, M.; Kim, B. \& Inoue, H. (2002). Motion design of a starfishshaped gel robot made of electroactive polymer gel. Robotics and Autonomous Systems, Vol.40, No.2-3, (August 2002), pp. 185-191.
14) Huber, D. L.; Manginell, R. P.; Samara, M. A.; Kim, B. \& Bunker, B. C. (2003). Programmed Adsorption and Released of proteins in a Microfluidic device, Science, Vol.301, No.5631, (July 2003), pp. 352-354.

15) Beebe, D. J.; Moore, J. S.; Bauer, J. M.;Yu, Q.;Liu, R. H.;Devadoss, C.; Jo, B. H. (2000). Functional hydrogel structures for autonomous flow control inside microfluidic channels, Nature, 404, pp. 588-590.

16) L. Dong and H. Jiang (2007) Autonomous microfluidics with stimuli-responsive hydrogels, Soft Matter,2007, 3, pp. 12231230

17) E. W. H. Jager, E. Smela, O. Inganäs (2000). Microfabricating Conjugated Polymer Actuators, Science, 290, p.1540.

18) E W. H. Jager, O. Inganäs, I. Lundström (2000). Microrobots for Micrometer-Size Objects in Aqueous Media: Potential Tools for Single Cell Manipulation, Science, 288, p.2335.

19) Y. Tanaka, K. Morishima, T. Shimizu, A. Kikuchi, M. Yamato, T. Okano, T. Kitamori (2006) An actuated pump onchip powered by cultured cardiomyocytes, Lab Chip, 6, pp. $230-235$.

20) Y. Tanaka, K. Morishima, T. Shimizu, A. Kikuchi, M. Yamato, T. Okano, T. Kitamori (2006) An actuated pump onchip powered by cultured cardiomyocytes, Lab Chip, 6, pp. 362-368.

21) K. Morishima, Y. Tanaka, M. Ebara, T. Shimizu, M. Yamato, A. Kikuchi, T. Okano, T. Kitamori (2006) Demonstration of a bio-microactuator powered by cultured cardiomyocytes coupled to hydrogel micropillars, Sens. Actuator B Chem., 119, pp. 345-350.

22) Zaikin, A.N.; Zhabotinsky, A.M. (1970). Concentration Wave propagation in two-dimensional liquid-phase self-oscillating system, Nature, 225, pp. 535-537.

23) Reusser, E.J.; Field, R.J. (1979). The transition from phase waves to trigger waves in a model of the Zhabotinskii reaction, Journal of the American Chemical Society, 101, pp. 1063-1071.

24) Nicolis, G.; Prigogine, I. (1997). Self Orgainization in Nonequilibrium Systems; Wiley: New York, NY, USA. 
25) Field, R.J.; Burger, M. (1985). Oscillations and Traveling Waves in Chemical Systems; John Wiley \& Sons: New York, NY, USA.

26) Field, R.J.; Noyes, R. M. (1974). Oscillations in chemical systems. IV. Limit cycle behavior in a model of a real chemical reaction, Journal of Chemical Physics, 60, pp. 1877 1884

27) Gyorgyi, L.; Turanyi, T.; Field, R J. (1990). Mechanistic details of the oscillatory Belousov-Zhabotinskii reaction, Journal of Chemical Physics, 94, pp. 7162-7170

28) V. Labrot, P. De Kepper, J. Boissonade, I. Szalai, and F. Gauffre (2005) Wave Patterns Driven by Chemomechanical Instabilities in Responsive Gels, J. Chem. Phys., vol. 109, no. 46, pp. 21476-21480.

29) Ishiwatari, T.; Kawaguchi, M.; Mitsuishi, M. (1984). Oscillatry reactions in polymer systems, Journal of Polymer Science Part A: Polymer Chemistry, 22, pp. 2699-2704

30) Yoshida, R.; Takahashi, T.; Yamaguchi, T.; Ichijo, H. (1996). Self-oscillating gel, Journal of the American Chemical Society, 118, pp. 5134-5135.

31) Hara, Y.; Yoshida, R. Self-oscillation of polymer chains induced by the Belousov-Zhabotinsky reaction under acidfree conditions. Journal of Physical Chemistry B 2005, 109, pp. 9451-9454.

32) Hara, Y.; Yoshida, R. (2009). Damping behavior of aggregation-disaggregation self-oscillation for a polymer chain, Macromolecular Rapid Communications, 30, pp. $1656-$ 1662 .

33) Hara, Y.; Sakai, T.; Maeda, S.; Hashimoto, S.; Yoshida, R. (2005).b Self-oscillating soluble-insoluble changes of polymer chain including an oxidizing agent induced by the BelousovZhabotinsky reaction, Journal of Physical Chemistry B, 109, pp. 23316-23319.

34) Hara, Y.; Yoshida, R. (2008). A viscosity self-oscillation of polymer solution induced by the BZ reaction under acid-free condition, Journal of Chemical Physics, 128, 224904.

35) Hara, Y.; Yoshida, R. (2008). Self-oscillating polymer fueled by organic acid. Journal of Physical Chemistry B, 112, pp. $8427-8429$

36) Y. Hara, S. Maeda, S. Hashimoto, R. Yoshida (2010) Molecular Design and Functional Control of Novel Selfoscillating Polymers, Int. J. Mol. Sci., 11, pp.704-718.

37) Y. Hara, S. Maeda, T. Mikanohara, H. Nakagawa, S. Nakamaru, S. Hashimoto (2012), Novel Self-Oscillating Polymer Actuators for Soft Robot, Smart Actuation and Sensing Systems - Recent Advances and Future Challenges, pp.311-343.

38) Maeda, S.; Hara, Y.; Yoshida, R.; Hashimoto, S. (2008). Control of the dynamic motion of a gel actuator driven by the Belousov-Zhabotinsky reaction, Macromolecular Rapid Communications, 29, pp. 401-405.

39) Maeda, S.; Hara, Y.; Sakai. T.; Yoshida, R.; Hashimoto, S. (2007). Self-walking gel, Advanced Materials, 19, pp. 3480-3484.

40) Maeda, S.; Hara, Y.; Yoshida, R.; Hashimoto, S. (2008). Peristaltic motion of polymer gels, Angewandte Chemie International Edition, 47, pp. 6690-6693.

41) Nakamaru, S,; Maeda, S. ; Hara, Y.; Hashimoto, S. (2009). Control of Autonomous Swelling-Deswelling Behavior for a Polymer gel. Journal of Physical Chemistry B, 2009, 113, pp. 4609-4613.

42) Hara, Y.; Yoshida, R. (2005). Control of oscillating behavior for the self-oscillating polymer with $\mathrm{pH}$-control site, Langmuir, 21, pp. 9773-9776. 